\title{
Analisa Biomassa dan Kandungan Logam Berat Pada Beras Merah Hasil Pemupukan Kompos Sludge dari Pabrik Kertas dan Pulp
}

\author{
${ }^{1}$ Thamzil Las*, ${ }^{2}$ Hilman Affandi, ${ }^{1}$ Sandra Hermanto, ${ }^{1}$ Farhat Etriya \\ ${ }^{1)}$ Program Studi Kimia FST UIN Syarif Hidayatullah Jakarta \\ ${ }^{2)}$ Balai Penelitian SEAMEO BIOTROP Bogor
}

\begin{abstract}
Abstrak
Pabrik kertas dan pulp menghasilkan limbah cair dan limbah padat (sludge). Limbah cair dikelola melalui instalansi pengelolaan air limbah (IPAL), sedangkan sludge hanya di timbun dalam tanah. Upaya yang dilakukan untuk mengelola sludge adalah diubah menjadi pupuk melalui pengomposan, karena sludge mengandung unsur hara yang dibutuhkan oleh tanaman. Penelitian ini bertujuan menguji kandungan logam berat yang terdapat pada sampel padi merah hasil pemupukan kompos sludge yang diperoleh dari penelitian sebelumnya. Dari tanaman padi merah terlebih dahulu dilakukan uji biomassa, selanjutnya dilakukan pengujian kadar protein dan kadar logam, terhadap beras merah. Analisis kandungan protein dengan metode Kjedahl dan pengukuran konsentrasi logam dan logam berat dengan metode spektrofotometer serapan atom. Hasil penelitian menunjukkan bahwa padi merah hasil pemupukan kompos sludge memiliki biomassa yang lebih tinggi dari pada kontrol (yang tidak dilakukan pemupukan kompos sludge). Peningkatan optimal biomassa dan kadar protein pada pemupukan kompos sludge $3 \mathrm{~kg} / \mathrm{m}^{2}$ yaitu 78 gram dan $11,1 \%$. Biomassa tanaman padi meningkat sebanyak 20 gram (dari 58 gram menjadi 78 gram) ketika pada pemupukan kompos sludge $0 \mathrm{~kg} / \mathrm{m}^{2}$ menjadi $3 \mathrm{~kg} / \mathrm{m}^{2}$. Kandungan protein beras merah meningkat sebanyak 2,8\% (dari 8,3\% menjadi $11 \%$ ) ketika pada pemupukan kompos sludge $0 \mathrm{~kg} / \mathrm{m}^{2}$ menjadi $3 \mathrm{~kg} / \mathrm{m}^{2}$. Hasil analisis logam pada beras merah menunjukkan penambahan dosis kompos sludge tidak menaikkan kandungan logam $(\alpha=0,05)$. Kandungan logam $\mathrm{Cu}, \mathrm{Zn}, \mathrm{Mn}$ dan Fe berturut-turut 2,41 ppm; 7,77 ppm; 32,7 ppm dan 37,71 ppm. Kandungan logam $\mathrm{Cu}$ dan $\mathrm{Zn}$ yang teranalisis masih aman untuk beras. Logam berat seperti $\mathrm{Pb}, \mathrm{Cd}$ dan $\mathrm{Cr}$ tidak terdeteksi walaupun pada sampel yang pemupukannya $4,5 \mathrm{~kg} / \mathrm{m}^{2}$.
\end{abstract}

Kata kunci : Sludge, Beras Merah, Logam Berat, Biomassa

\begin{abstract}
Pulp and paper industries are produce the liquid waste and semi-solid waste such as sludge. Liquid waste is to treated with the installation for treatment of liquid waste (IPAL), while the sludge waste is only buried on land. For that, the important mentions is needed to manage sludge to be change into the fertilizer through composting method, in which sludge is composed with the nutrient component to be useful for plant growing. The main purpose of this research is to measured the trace element composition from the red paddy after use the compost made from waste of sludge. Analysis are performed by Kjedahl for protein content, and Atomic adsorption Spectrophotometer for heavy metal contents. The result showed that protein content from red paddy fertilized by compost have a higher biomass than on red paddy for control without compost. The increasing of biomass and protein content using sluge compos on $3 \mathrm{~kg} / \mathrm{m} 2$ found to be $78 \mathrm{~g}$ and $11,1 \%$ respectively. The biomass of red paddy increase to $20 \mathrm{~g}$ (from $58 \mathrm{~g}$ without compost to $78 \mathrm{~g}$ wit 3 $\mathrm{kg} / \mathrm{m}_{2}$ compost). On the other hand, protein content of red rice from red paddy increase $2,8 \%$ from $8,2 \%$ without compost to $11 \%$ with $3 \mathrm{~kg} / \mathrm{m}^{2}$ compost. The analytical result of red rice shown that adding the dose of sludge compost, to red paddy growing is not increased the heavy metal content of the plant $(\mathrm{a}=0.05)$. The $\mathrm{Cu}, \mathrm{Zn}, \mathrm{Mn}$, and $\mathrm{Fe}$ content of red house are found 2,4 ppm, 7,77 ppm, $32,7 \mathrm{ppm}$ dan $37,71 \mathrm{ppm}$ respectively. The $\mathrm{Cu}$ and $\mathrm{Zn}$ contents obtained meet all the safely for rice, while the $\mathrm{Pb}, \mathrm{cd}$, and $\mathrm{Cr}$ were undetected from the sampel which was used the compost 4,5 $\mathrm{kg} / \mathrm{m}^{2}$
\end{abstract}

Keyword : Sludge, red rice, heavy metal, biomass. 


\section{PENDAHULUAN}

Peningkatan kegiatan perekonomian terutama sektor industri, senantiasa menimbulkan dampak positif dan dampak negatif. Dampak positif antara lain meningkatkan perekonomian, meningkatkan kesempatan kerja, meningkatkan taraf hidup masyarakat dan pertumbuhan ekonomi nasional. Dampak negatif yang dapat ditimbulkan, apabila penanganan limbah industri tersebut tidak tepat sehingga mengakibatkan pencemaran lingkungan (Affandi, H. 2004).

Kebutuhan kertas yang semakin meningkat telah mendorong berkembangnya pabrik kertas dan pulp. Pabrik kertas dan pulp ini tidak hanya memproduksi kertas langsung dari kayu sebagai bahan baku utama pembuatan kertas, tetapi ada diantara pabrik kertas dan pulp yang mengolah kembali kertas bekas pakai menjadi kertas baru yang siap pakai, salah satunya ialah PT Indah Kiat Pulp $\&$ Paper (PT IKPP) Serang Mill.

Kapasitas produksi pabrik kertas dan pulp dalam jumlah besar dapat memenuhi kebutuhan kertas dalam negeri dan menjadikannya sebagai sumber devisa negara. Namun demikian, pengelolaan limbah sampai saat ini masih menjadi permasalahan bagi pabrik kertas dan pulp di Indonesia. Pengelolaan limbah yang dilakukan oleh pabrik kertas dan pulp adalah pengelolaan limbah cair dan limbah padat (sludge). Pengelolaan limbah cair dilakukan dengan instalansi pengelolaan air limbah (IPAL). Untuk mengatasi permasalahan limbah padat (sludge), pabrik kertas dan pulp mulai mencari alternatif pengelolaan sludge agar dapat memberikan manfaat ganda yaitu dapat mengurangi limbah dan bermanfaat bagi lingkungan. Sludge mengandung bahan organik makro dan mikro yang merupakan unsur hara yang diperlukan tanaman yaitu: N, $\mathrm{C}$ organik, $\mathrm{P}, \mathrm{K}, \mathrm{Ca}, \mathrm{Mg}, \mathrm{Cu}$ dan $\mathrm{Zn}$ (Scott et al.,1995).

Teknik pengomposan dapat dijadikan solusi penyelesaian permasalahan pengelolaan sludge (Das, K.C. \& E.W. Tollner. 1995). Hal ini disebabkan karena teknik pengomposan memberikan kemungkinan pemanfaatan sludge menjadi kompos yang selanjutnya dapat digunakan sebagai pupuk organik. Berdasarkan kajian karakteristik bahan-bahan sisa dan didukung hasil penelitian menunjukkan adanya potensi sludge yang dapat meningkatkan kesuburan tanah (ASAC,1987). Upaya yang dapat dilakukan adalah mengolah sludge menjadi pupuk melalui pengomposan.

Kertas bekas sebagai bahan baku proses pembuatan kertas menimbulkan kekhawatiran adanya logam berat yang bersumber dari tinta. Adanya logam berat dalam limbah perlu mendapat perhatian dalam kaitannya dengan alternatif pemanfaatan sludge sebagai kompos. Adapun logam berat yang diduga terdapat dalam sludge yaitu $\mathrm{Cd}$ (kadnium), $\mathrm{Cr}$ (kromium) dan Pb (timbal) (AEP,1999). Telah dilakukan penelitian sebelumnya mengenai pengomposan sludge dan penanaman padi merah oleh SEAMEO BIOTROP. Oleh karena itu, dilakukan analisis terhadap tanaman padi merah yang mendapat hasil pemupukan kompos sludge untuk mengetahui kandungan logam dan logam berat yang terdapat pada bagian biji beras merah.

\section{METODE PENELITIAN}

\section{Bahan dan Alat}

Alat-alat yang digunakan dalam penelitian ini adalah kertas saring Whatman No. 1, cup film, pipet volumetri $1 \mathrm{~mL}$ dan 10 $\mathrm{mL}$ cawan alumunium, cawan porselin, gegep, neraca analitik merk Dragon Taledo, buret, desikator. Labu Kjeldahl, labu distilasi, seperangkat distilasi nitrogen Buchi 316, oven Heraeus 6000, oven WTC Binder type 01115250000010, hot plate themolyne stirring, tanur furnance industriefenbau seri 2804 dan spektrofotometer serapan atom (SSA) Analytik Jena AG novAA 300.

Bahan-bahan yang digunakan adalah tanaman padi merah, hasil pemupukan kompos sludge yang diperoleh dari SEAMEO BIOTROP, larutan asam sulfat $\left(\mathrm{H}_{2} \mathrm{SO}_{4}\right)$ pekat p.a, $\mathrm{H}_{2} \mathrm{O}_{2} 50 \%$, larutan natrium hidroksida (NaOH) $50 \%$, larutan asam borat $\left(\mathrm{H}_{3} \mathrm{BO}_{3}\right) 1 \%$, indikator Conway (bromo cresol green dan metil merah), $\mathrm{HCl} 1 \mathrm{~N}, \mathrm{HCl} 0,02 \mathrm{~N}, \mathrm{HCl} 25 \%$ dan indikator phenolphtalein (pp) $0,1 \%$.

\section{Penanaman Padi Merah yang Digunakan sebagai Sampel}

Pengomposan dan penanaman padi merah yang ditambahkan variasi dosis kompos 
sludge dilakukan oleh SEAMEO BIOTROP. Media tanaman padi merah dibagi menjadi 8 petak sawah. Luas setiap petak sawah sebesar $7 \times 7 \mathrm{~m}$ yang terisi 576 tanaman padi dengan jarak tanam $30 \times 30 \mathrm{~cm}$. Tanaman padi merah yang dipakai sebagai contoh penelitian berumur 4 bulan, yang diambil secara acak sebanyak 10 rumpun per petak untuk mewakili seluruh tanaman padi dalam satu petak. Setiap petak ada 2 ulangan yaitu, tanaman 1-5 sebagai ulangan pertama dan tanaman 6-10 sebagai ulangan 2.

Sampel yang digunakan pada percobaan ialah tanaman padi merah yang berasal dari Serang dan telah mendapat perlakuan. Perlakuan yang dimaksud ialah menambahkan kompos sludge dan pupuk dasar (urea, TSP dan $\mathrm{KCl}$ ). Dosis pupuk dasar yang ditambahkan untuk setiap perlakuan jumlahnya sama yaitu urea $0,025 \mathrm{~kg} / \mathrm{m}^{2}$, TSP $0,0075 \mathrm{~kg} / \mathrm{m}^{2}$ dan $\mathrm{KCl} 0,005 \mathrm{~kg} / \mathrm{m}^{2}$, sedangkan variasi dosis kompos sludge yang ditambahkan ke masing-masing petak, yaitu $0 \mathrm{~kg} / \mathrm{m}^{2}$ (kontrol) pada petak 1 dan petak $7 ; 1,5 \mathrm{~kg} / \mathrm{m}^{2}$ pada petak 8 dan petak $2 ; 3 \mathrm{~kg} / \mathrm{m}^{2}$ pada petak 4 dan petak 3 dan $4,5 \mathrm{~kg} / \mathrm{m}^{2}$ pada petak 6 dan petak 5. Setiap perlakuan terdiri dari dua ulangan yaitu (A dan B) yang menyatakan tanah sawah dari petak A dan petak B. Tabel 1 menunjukkan kode setiap plot tanaman padi.

Tabel 1. Kode Setiap Plot Tanaman Padi

\begin{tabular}{|c|c|c|c|}
\hline $\begin{array}{c}\text { Petak 1A } \\
\text { P-s1A }\end{array}$ & $\begin{array}{c}\text { Petak 2B } \\
\text { P-s2B }\end{array}$ & $\begin{array}{c}\text { Petak 3B } \\
\text { P-s3B }\end{array}$ & $\begin{array}{c}\text { Petak 4A } \\
\text { P-s3A }\end{array}$ \\
\hline $\begin{array}{c}\text { Petak 5B } \\
\text { P-s4B }\end{array}$ & Petak 6A & Petak 7B & Petak 8A \\
& P-s1B & P-s2A \\
\hline
\end{tabular}

Keterangan:

$\mathrm{A}=$ Tanah sawah petak $\mathrm{A}$

$\mathrm{B}=$ Tanah sawah petak B

$\mathrm{P}=$ Tanaman padi merah

Dengan demikian terdapat empat jenis sampel yang dipakai dalam penelitian ini yaitu:

S1 = Padi merah yang tidak dilakukan pemupukan kompos sludge

$\mathrm{S} 2$ = Padi merah hasil pemupukan dengan dosis kompos sludge $1,5 \mathrm{~kg} / \mathrm{m}^{2}$

S3 = Padi merah hasil pemupukan dengan dosis kompos sludge $3 \mathrm{~kg} / \mathrm{m}^{2}$
S4 = Padi merah hasil pemupukan dengan dosis kompos sludge $4,5 \mathrm{~kg} / \mathrm{m}^{2}$

\section{Analisa Biomassa Tanaman Padi Merah}

Tanaman padi sebelum dianalisis terlebih dahulu dibersihkan dengan air untuk menghilangkan tanah, debu atau kotoran yang menempel. Kemudian dipisahkan antara akar, batang dan gabah keseluruhan dari tanaman padi. Selanjutnya seluruh tanaman padi dikeringkan dalam oven pada suhu $60{ }^{\circ} \mathrm{C}$ selama 48 jam. Lalu ditimbang seluruh tanaman padi (Lesmono, 2005).

\section{Preparasi Kimia}

Preparasi kimia dilakukan terhadap 100 butir gabah beras merah, yang mula-mula gabah dibuang, lalu berasnya ditumbuk sampai antara gabah dan sekam terpisah atau yang lazim disebut beras. Dari sampel beras merah dilakukan analisa kadar air, kadar $\mathrm{N}$ total serta logam dan logam berat.

\section{Analisa Kadar Air Beras Merah}

Beras merah yang sudah dihaluskan ditimbang \pm 1 gram lalu dimasukkan ke dalam cawan alumunium yang bersih dan kering serta telah diketahui bobot tetapnya, kemudian bobot cawan beserta sampel beras merah ditimbang. Sampel tersebut dikeringkan di dalam oven dengan tutup terbuka pada suhu $105{ }^{\circ} \mathrm{C}$ selama 24 jam. Cawan dan isinya didinginkan dalam keadaan tertutup di dalam desikator sampai mencapai suhu kamar dan ditimbang sampai bobotnya tetap.

\section{Analisa Nitrogen Total Metode Kjedahl}

Contoh sample dimasukkan ke dalam labu Kjedahl $100 \mathrm{~mL}$. Ditambahkan $25 \mathrm{~mL}$ $\mathrm{H}_{2} \mathrm{SO}_{4}$ ke dalam labu dan digoyangkan perlahan agar terbasahi oleh $\mathrm{H}_{2} \mathrm{SO}_{4}$, kemudian dipanasi labu pada alat destruksi nitrogen atur suhu pada posisi $200{ }^{\circ} \mathrm{C}$ selama \pm 10 menit. Selanjutnya diatur kembali posisi pengatur panas pada posisi $340{ }^{\circ} \mathrm{C}$ sampai destruksi sempurna. Didinginkan contoh kemudian ditambahkan $\mathrm{H}_{2} \mathrm{O}_{2}$ beberapa tetes untuk oksidasi hingga larutan jernih. Dipanaskan kembali contoh pada alat destruksi hingga larutan jernih, lalu didinginkan. Ditambahkan $50 \mathrm{~mL}$ aquades dan digoyangkan sebentar, 
kemudian dipindahkan isi labu ukur secara kuantitatif ke dalam labu ukur $100 \mathrm{~mL}$ dikocok hingga homogen. Larutan yang didapat adalah larutan pekat. Dipipet $10 \mathrm{~mL}$ larutan pekat ke dalam labu distilasi, kemudian ditambahkan 5 tetes indikator phenolphtalein (pp) $0,1 \%$ dan


distilasi. Ditampung distilat dalam erlenmeyer yang berisi campuran $10 \mathrm{~mL} \mathrm{H}_{3} \mathrm{BO}_{3} 1 \%$ dan 5 tetes indikator Conway sampai isinya menjadi $\pm 100 \mathrm{~mL}$. Dititrasi distilat dengan $\mathrm{HCl} 0,02 \mathrm{~N}$ yang telah dibakukan sampai terjadi perubahan warna dari hijau ke merah muda. Dari analisa nitrogen total kemudian di konversi ke kadar protein. Kadar protein beras dihitung dari nilai nitrogen Kjeldahl dengan faktor pengali 5,95 untuk beras (Winarno, 1997).

\section{Analisa Logam dengan Spektrofotometer Serapan Atom}

Beras merah yang sudah dihaluskan ditimbang $\pm 0,5$ gram lalu dimasukkan ke dalam cawan porselin kemudian contoh tersebut dimasukkan ke dalam tanur dengan tutup terbuka dan dipanaskan pada suhu 300 ${ }^{\circ} \mathrm{C}$ selama setengah jam. Suhu tanur dinaikkan sampai suhu $500^{\circ} \mathrm{C}$ sehingga contoh terabukan (warna putih). Lalu cawan dan isinya didinginkan dalam keadaan tertutup. Kemudian ditambah $1 \mathrm{~mL} \mathrm{HCl} \mathrm{25 \%} \mathrm{hingga}$ larut lalu dipanaskan dengan menggunakan hootplat sampai $\mathrm{HCl}$ menguap. Contoh pada cawan yang telah diuapkan dilarutkan dengan $10 \mathrm{~mL} \mathrm{HCl} 1 \mathrm{~N}$ dan disaring. Hasil saringan diencerkan 10x dan larutan diukur untuk logam $\mathrm{Cu}, \mathrm{Zn}, \mathrm{Mn}, \mathrm{Fe}, \mathrm{Pb}, \mathrm{Cd}$ dan $\mathrm{Cr}$ menggunakan spektrofotometer serapan atom (SSA) dengan pengukuran seperti pada Tabel 2 (Christian, et. al., 1986).

Tabel 2. Pengukuran Spektrofotometer Serapan Atom (SSA).

\begin{tabular}{|c|c|c|c|c|}
\hline Pengukuran & $\begin{array}{c}\text { Panj } \\
\text { Gelombang } \\
(\lambda \text { maks })\end{array}$ & $\begin{array}{l}\text { Lebar } \\
\text { celah }\end{array}$ & $\begin{array}{l}\text { Kuat arus } \\
\text { lampu }\end{array}$ & Tipe nyala \\
\hline $\mathrm{Cu}$ & 324,8 & 1,2 & 3,0 & $\mathrm{C}_{2} \mathrm{H}_{2} /$ Udara \\
\hline $\mathrm{Zn}$ & 213,9 & 0,5 & 4,0 & $\mathrm{C}_{2} \mathrm{H}_{2} /$ Udara \\
\hline $\mathrm{Mn}$ & 279,5 & 0,2 & 10,0 & $\mathrm{C}_{2} \mathrm{H}_{2} /$ Udara \\
\hline $\mathrm{Fe}$ & 248,3 & 0,2 & 8,0 & $\mathrm{C}_{2} \mathrm{H}_{2} /$ Udara \\
\hline $\mathrm{Pb}$ & 283,3 & 1,2 & 4 & $\mathrm{C}_{2} \mathrm{H}_{2} /$ Udara \\
\hline $\mathrm{Cd}$ & 228,8 & 1,2 & 2,0 & $\mathrm{C}_{2} \mathrm{H}_{2} /$ Udara \\
\hline $\mathrm{Cr}$ & 357,9 & 0,2 & 8,0 & $\mathrm{C}_{2} \mathrm{H}_{2} /$ Udara \\
\hline
\end{tabular}

\section{HASIL DAN PEMBAHASAN}

Pengunaan pupuk anorganik seperti urea, TSP dan $\mathrm{KCl}$ dalam waktu lama dan terus-menerus dapat menurunkan kadar bahan organik tanah. Bahan organik merupakan salah satu unsur pembentukan kesuburan tanah. Oleh karena itu, upaya memperbaiki kesuburan tanah dengan penambahan bahan organik sangatlah penting. Bahan organik ini berasal dari kompos sludge yang telah mengalami proses dekomposisi terlebih dahulu, sehingga dapat digunakan oleh tanaman. Penggunaan pupuk kompos secara kombinasi dengan pupuk anorganik sangat berperan meningkatkan produktivitas lahan sawah melalui perbaikan struktur tanah dan penyediaan unsur hara.

Secara umum kompos sangat bermanfaat untuk menyuburkan tanah dengan adanya kandungan bahan organik yang tinggi, karena sifat kestabilannya maka bahan organik dalam kompos akan terdegradasi secara perlahan dan tertahan secara efektif untuk waktu yang lebih lama dibandingkan bahan organik dari limbah yang belum dikomposkan (Richard T, 1996). Kompos sangat kaya akan unsur hara seperti besi (Fe), Boron (B), Belerang (S, Sulfur), Kapur (Ca), Magnesium $(\mathrm{Mg})$ dan banyak lagi lainnya. Keberadaan unsur-unsur tersebut sangatlah penting bagi pertumbuhan tanaman (CPIS,1992).

\section{Biomassa Tanaman Padi Merah}

Hasil pertumbuhan rata-rata biomassa tanaman padi merah yang diberi perlakuan variasi dosis kompos Sludge adalah sebagaimana terlihat pada gambar 1 .

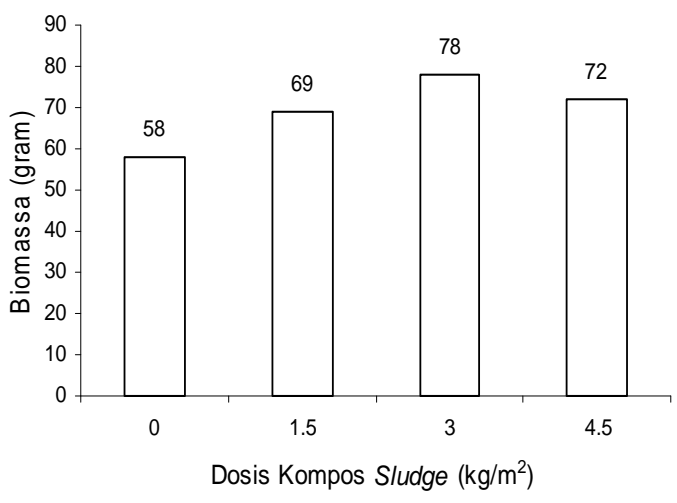

Gambar 1. Grafik Rata-rata Biomassa Tanaman Padi Merah yang Diberi Perlakuan Variasi Dosis Kompos Sludge 
Dari grafik tersebut dapat dilihat bahwa hasil pemupukan kompos sludge meningkatkan biomassa tanaman padi merah dibandingkan kontrol (yang tidak dilakukan pemupukan kompos sludge). Hasil pemupukan dengan dosis kompos sludge $3 \mathrm{~kg} / \mathrm{m}^{2}$ menghasilkan kemampuan biomassa tanaman padi merah terbaik yaitu 78 gram. Akan tetapi, terjadi penurunan biomassa pada hasil pemupukan dengan dosis $4,5 \mathrm{~kg} / \mathrm{m}^{2}$ yaitu 72 gram. Dari hasil pengamatan biomassa tanaman padi merah menunjukkan bahwa hasil pemupukan kompos sludge meningkatkan kualitas pertumbuhan tanaman padi merah yang bertambahnya bobot biomassa, hal ini disebabkan karena ketersediaan unsur hara pada sludge yang dikomposkan mampu dirombak menjadi unsur yang lebih sederhana sehingga penyerapan unsur hara oleh akar tanaman menjadi lebih baik.

\section{Kadar Air Beras Merah}

Penentuan kadar air dilakukan untuk mengetahui faktor koreksi yang digunakan untuk menentukan kadar protein dan kandungan logam yang dinyatakan dalam persen dari bobot kering contoh. Kadar air yang dihasilkan relatif sama pada variasi kompos sludge tersebut dapat diilustrasikan sebagaimana Gambar 2.

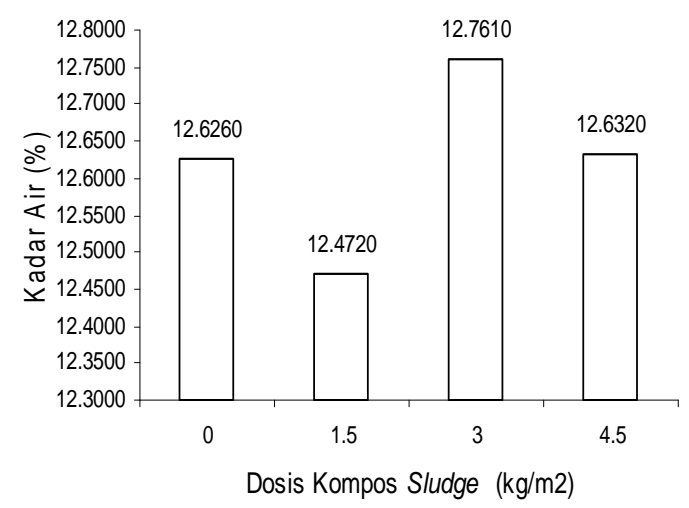

Gambar 2. Grafik Rata-rata Kadar Air Beras Merah yang Diberi Perlakuan Variasi Dosis Kompos Sludge

Berdasarkan Gambar 2 dapat dikatakan bahwa kadar air dalam beras merah pada hasil pemupukan kompos sludge relatif tetap. Menurut Juliano (1976) kandungan kadar air dalam beras merah adalah $14 \%$, sedangkan dari hasil penelitian rata-rata kadar air adalah $12 \%$. Hal ini mungkin disebabkan karena setelah padi tersebut dipanen kemudian dijemur, sehingga akan mengurangi kadar air yang terdapat pada beras merah. Kadar air mempengaruhi daya penyimpanan suatu bahan, semakin besar nilai kadar air maka waktu simpan bahan tersebut singkat atau mudah busuk karena adanya kemungkinan kontaminasi mikroorganisme.

\section{Kadar Protein Beras Merah}

Hasil analisa kadar protein Beras Merah yang diberi perlakuan variasi dosis kompos Sludge adalah sebagaimana terlihat pada gambar 3 .

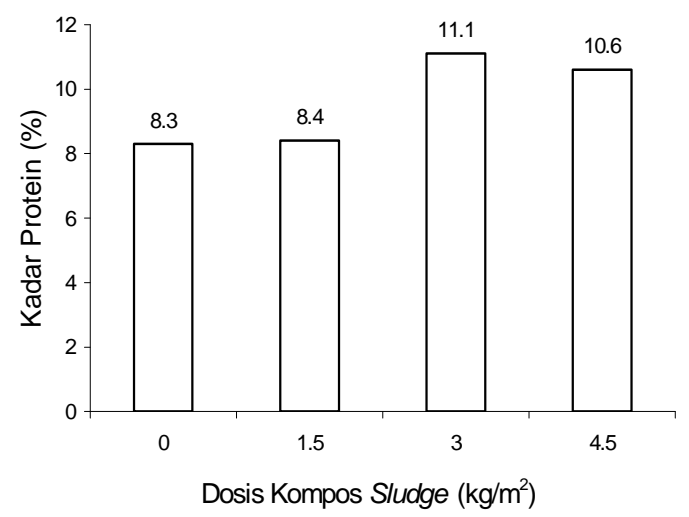

Gambar 3. Grafik Rata-rata Kadar Protein Beras Merah yang Diberi Perlakuan Variasi Dosis Kompos Sludge

Berdasarkan grafik tersebut bahwa hasil pemupukan kompos sludge meningkatkan kadar protein, bila dibandingkan dengan kontrol (yang tidak dilakukan pemupukan kompos sludge). Kadar protein beras merah optimal pada hasil pemupukan $3 \mathrm{~kg} / \mathrm{m}^{2}$ sebanyak $11,1 \%$, sedangkan pada hasil pemupukan $4,5 \mathrm{~kg} / \mathrm{m}^{2}$ mengalami penurunan yaitu $10,6 \%$. Faktor yang menyebabkan besarnya kadar protein beras adalah populasi tanaman, waktu dan cara pemupukan nitrogen, pengelolaan pengairan, pengendalian gulma dan waktu tanam (Ismunadji et al.,1991).

\section{Kandungan Logam dalam Beras Merah}

Kandungan logam yang terkandung pada beras merah dapat ditentukan dengan menentukan kadar abunya. Unsur-unsur logam $\mathrm{Cu}, \mathrm{Zn}, \mathrm{Mn}$ dan $\mathrm{Fe}$ merupakan unsur hara yang 
dibutuhkan tanaman dalam jumlah sedikit (Osman,1996). Logam berat dapat diserap oleh tanaman pada beberapa bagian atau jaringan tanaman dengan konsentrasi yang berbeda. Tabel 3 menunjukkan rata-rata hasil pengukuran logam yang dapat terdapat pada bagian biji beras merah terhadap hasil pemupukan kompos sludge. Logam-logam tersebut berasal dari hasil penyerapan unsur hara mikro yang tersedia dalam tanah ataupun dari kompos sludge oleh tanaman. Logam $\mathrm{Pb}$, $\mathrm{Cd}$ dan $\mathrm{Cr}$ tidak terdeteksi hingga hasil pemupukan dosis kompos sludge $4,5 \mathrm{~kg} / \mathrm{m}^{2}$.

Tabel 3. Rata-rata Pengukuran Logam Berat dalam Beras Merah

\begin{tabular}{|c|c|c|c|c|}
\hline $\begin{array}{c}\text { Kadar } \\
\text { logam } \\
(\mathrm{ppm})\end{array}$ & $\begin{array}{c}\mathrm{S} 1 \\
\left(0 \mathrm{~kg} / \mathrm{m}^{2}\right)\end{array}$ & $\begin{array}{c}\mathrm{S} 2 \\
\left(1.5 \mathrm{~kg} / \mathrm{m}^{2}\right)\end{array}$ & $\begin{array}{c}\mathrm{S} 3 \\
\left(3 \mathrm{~kg} / \mathrm{m}^{2}\right)\end{array}$ & $\begin{array}{c}\mathrm{S} 4 \\
\left(4.5 \mathrm{~kg} / \mathrm{m}^{2}\right)\end{array}$ \\
\hline $\mathrm{Cu}$ & 2.41 & 0.65 & 1.43 & 1.25 \\
\hline $\mathrm{Zn}$ & 9.14 & 8.53 & 7.26 & 7.14 \\
\hline $\mathrm{Mn}$ & 32.70 & 27.83 & 12.78 & 8.17 \\
\hline $\mathrm{Fe}$ & 36.81 & 36.66 & 35.18 & 32.70 \\
\hline $\mathrm{Pb}$ & $\mathrm{Ttd}$ & $\mathrm{Ttd}$ & $\mathrm{Ttd}$ & $\mathrm{Ttd}$ \\
\hline $\mathrm{Cd}$ & $\mathrm{Ttd}$ & $\mathrm{Ttd}$ & $\mathrm{Ttd}$ & $\mathrm{Ttd}$ \\
\hline $\mathrm{Cr}$ & $\mathrm{Ttd}$ & $\mathrm{Ttd}$ & $\mathrm{Ttd}$ & Ttd \\
\hline
\end{tabular}

*) Keterangan: ttd (tidak terdeteksi)

mdl (measurement detection limited)

mdl $\mathrm{Pb} 0,009$ ppm

mdl $\mathrm{Cd}<0,0004 \mathrm{ppm}$

mdl $\mathrm{Cr}<0,015 \mathrm{ppm}$

Hasil percobaan analisis logam $\mathrm{Cu}$ menunjukkan hasil pemupukan kompos sludge $1,5 \mathrm{~kg} / \mathrm{m}^{2}$ yaitu $0,65 \mathrm{ppm}$ lebih rendah dibandingkan dosis kontrol (yang tidak dilakukan pemupukan kompos sludge) yaitu 2,41 ppm. Peningkatan kandungan logam $\mathrm{Cu}$ terjadi pada hasil pemupukan dosis $3 \mathrm{~kg} / \mathrm{m}^{2}$ yaitu $1,43 \mathrm{ppm}$. Akan tetapi terjadi penurunan kandungan logam $\mathrm{Cu}$ pada hasil pemupukan kompos sludge $4,5 \mathrm{~kg} / \mathrm{m}^{2}$. Kenaikan dan penurunan kandungan logam $\mathrm{Cu}$ yang tidak konsisten menunjukkan bahwa pemupukan kompos sludge tidak begitu berpengaruh terhadap kandungan logam $\mathrm{Cu}$. Kandungan logam $\mathrm{Cu}$ yang teranalisis apabila dibandingkan dengan batas konsentrasi maksimum yang telah ditetapkan oleh badan pengawasan obat dan makanan menunjukkan bahwa kandungan logam $\mathrm{Cu}$ masih berada di bawah batas konsentrasi maksimum untuk beras yaitu $10 \mathrm{ppm}$. Hasil uji sidik ragam menunjukkan bahwa perlakuan dosis kompos tidak berpengaruh terhadap penyerapan logam $\mathrm{Cu}$ pada beras merah $(\mathrm{P}=0.156839>0.05)$.

Hasil percobaan analisis logam $\mathrm{Zn}$ menunjukkan bahwa kandungan logam $\mathrm{Zn}$ pada beras merah mengalami penurunan seiring dengan penambahan hasil pemupukan kompos sludge dibandingkan kontrol (yang tidak dilakukan pemupukan kompos sludge). Logam $\mathrm{Zn}$ terserap paling tinggi pada kontrol yaitu 9,14 ppm. Sedangkan logam $\mathrm{Zn}$ terserap paling rendah pada hasil pemupukan kompos sludge $4,5 \mathrm{~kg} / \mathrm{m}^{2}$ yaitu $7,14 \mathrm{ppm}$. Kandungan logam $\mathrm{Zn}$ yang teranalisis apabila dibandingkan dengan batas konsentrasi maksimum yang telah ditetapkan oleh badan pengawasan obat dan makanan menunjukkan bahwa kandungan logam $\mathrm{Zn}$ masih berada di bawah batas konsentrasi maksimum untuk beras yaitu $40 \mathrm{ppm}$. Hasil uji sidik ragam menunjukkan bahwa perlakuan dosis kompos tidak berpengaruh terhadap kandungan logam $\mathrm{Zn}$ pada beras merah $(\mathrm{P}=0.294687>0.05)$.

Kandungan logam Mn pada beras merah mengalami penurunan seiring dengan penambahan hasil pemupukan kompos sludge dibandingkan kontrol (yang tidak dilakukan pemupukan kompos sludge). Logam Mn terserap maksimum pada kontrol sebanyak 32,7 ppm, sedangkan kandungan logam $\mathrm{Mn}$ minimum pada hasil pemupukan $4,5 \mathrm{~kg} / \mathrm{m}^{2}$ sebanyak 8,17 ppm. Untuk logam Mn badan pengawasan obat dan makanan belum mempunyai batas konsentrasi maksimum. Namun demikian, logam Mn yang teranalisa masih berada di bawah batas konsentrasi maksimum untuk tanaman padi yaitu $70 \mathrm{ppm}$ (Sanchez, 1976).

Hasil percobaan analisis logam $\mathrm{Fe}$ menunjukkan bahwa kandungan logam $\mathrm{Fe}$ pada beras merah mengalami penurunan seiring dengan penambahan hasil pemupukan kompos sludge dibandingkan kontrol (yang tidak dilakukan pemupukan kompos sludge). Kandungan logam $\mathrm{Fe}$ maksimum pada kontrol sebanyak 36,81 ppm, sedangkan kandungan logam Mn minimum pada hasil pemupukan kompos sludge $4,5 \mathrm{~kg} / \mathrm{m}^{2}$ sebanyak $32,70 \mathrm{ppm}$. Penelitian Obata (1995) menunjukkan bahwa tanaman padi memerlukan unsur hara Fe lebih besar dibandingkan tanaman palawija lainnya. Hal ini sesuai dengan hasil penelitian bahwa konsentrasi logam Fe lebih besar dibandingkan 
dengan logam $\mathrm{Cu}, \mathrm{Zn}$ dan $\mathrm{Mn}$. Hasil uji sidik ragam menunjukkan bahwa perlakuan dosis kompos tidak berpengaruh terhadap kandungan logam $\mathrm{Fe}$ pada beras merah $(\mathrm{P}=$ $0.973184>0.05)$.

Berdasarkan hasil analisis logam timbal $(\mathrm{Pb})$, kadmium $(\mathrm{Cd})$ dan kromium $(\mathrm{Cr})$ tidak terdeteksi hingga hasil pemupukan kompos sludge $4,5 \mathrm{~kg} / \mathrm{m}^{2}$. Hal ini menunjukkan bahwa tidak ada penyerapan logam $\mathrm{Pb}, \mathrm{Cd}$ dan $\mathrm{Cr}$ sampai ke bagian biji beras merah. Logam timbal $(\mathrm{Pb})$ tidak termasuk unsur mikro yang dibutuhkan oleh tanaman padi, sehingga apabila logam ini terkandung dalam beras merah harus diwaspadai karena apabila terakumulasi dalam tubuh manusia melewati batas toleransinya akan bersifat toksik (Vouk, V. 1986). Efek logam $\mathrm{Pb}$ pada kesehatan manusia adalah menimbulkan kerusakan otak, kejang-kejang, kelainan ginjal, gangguan pencernaan bahkan kematian (Suharto, 2005).

Logam kadmium (Cd) merupakan logam berat tidak esensial atau beracun, dimana keberadaannya dalam tubuh belum diketahui manfaatnya atau bahkan dapat bersifat racun (Salt, et al., 1995). Menurut FAO-WHO kandungan kadmium yang ditetapkan untuk bahan pangan adalah 0,060,07 mg/orang/hari (Saeni,1997). Keracunan kadmium dalam jangka waktu lama dapat bersifat toksik pada paru-paru, tulang dan hati (Darmono,1995). Logam kromium (Cr) tidak terdeteksi hingga hasil pemupukan kompos sludge $4,5 \mathrm{~kg} / \mathrm{m}^{2}$. Hal ini menunjukkan bahwa tidak ada penyerapan logam $\mathrm{Cr}$ sampai ke bagian biji beras merah.

\section{KESIMPULAN}

Dari penelitian yang telah dilakukan, dapat disimpulkan bahwa:

1. Biomassa padi merah hasil pemupukan kompos sludge mengalami peningkatan bila dibandingkan kontrol. Peningkatan optimal biomassa padi merah pada hasil pemupukan kompos sludge $3 \mathrm{~kg} / \mathrm{m}^{2}$ yaitu 78 gram.

2. Kandungan protein beras merah hasil pemupukan kompos sludge mengalami peningkatan bila dibandingkan kontrol. Peningkatan optimal kadar protein beras merah pada hasil pemupukan kompos sludge $3 \mathrm{~kg} / \mathrm{m}^{2}$ yaitu $11,1 \%$.
3. Kandungan logam $\mathrm{Cu}, \mathrm{Zn} \mathrm{Mn}$ dan $\mathrm{Fe}$ tertinggi pada dosis kontrol yaitu 2,41 ppm; 7,77 ppm; 32,7 ppm dan 37,71 ppm. Kandungan logam $\mathrm{Cu}$ dan $\mathrm{Zn}$ di bawah konsentrasi maksimum menurut badan pengawasan obat dan makanan yaitu $\mathrm{Cu} 10$ ppm dan Zn 40 pmm.

4. Unsur logam berat $\mathrm{Pb}, \mathrm{Cd}$ dan $\mathrm{Cr}$ dalam beras merah tidak terdeteksi hingga hasil pemupukan kompos sludge $4,5 \mathrm{~kg} / \mathrm{m}^{2}$.

\section{UCAPAN TERIMA KASIH}

Pada kesempatan ini penulis mengucapkan terimakasih kepada Kepala Balai Penelitian SEAMEO BIOTROP Bogor dan Kepala Labaoratorium Tanah dan Tanaman IPB atas kesempatannya untuk melakukan penelitian ini.

\section{DAFTAR PUSTAKA}

1. Affandi, H. 2004. Penyusunan Pedoman Pemanfaatan Limbah Padat Pabrik Pulp dan Kertas untuk Lahan Pertanian SEAMEO BIOTROP. Kementerian Lingkungan Hidup. Bogor.

2. Alberta Enviromental Protection (AEP). 1999. Standard and Guidelines for The Land Application of Mechanical Pulp Mill Sludge to Agricultural Land. Albertanviromental Protection. Enviromental Sciences Division. Rdmonton Alberta 2: 4-7.

3. ASAC. 1987. Soil Quality Criteria Relative to Distrubance and Reclamation. Alberta Soils Advisory Comitte. Alberta Agriculture. Edmonton Alberta.

4. Christian, Gary. D. and James, E. Oreilly. 1986.. Instrumental Analysis Second edition. Allyn And Bacon, IAC. London.

5. CPIS. 1992. Panduan Teknik Pembuatan Kompos dan Sampah: Teori dan Aplikasi. Center for Policy and Implementation Study (CPIS). Jakarta.

6. Darmono. 1995. Logam dalam Sistem Biologi Mahluk Hidup. Universitas Indonesia. Jakarta.

7. Das, K.C. \& E.W. Tollner. 1995. Composting Pulp and Paper Industri Solid Waste Process. Design and Product Evaluation Atlanta.

8. Ismunadji, M \& S. Roechan. (eds). 1991. Hara Mineral Tanaman Padi. Pusat Penelitian dan Pengembangan Tanaman Pangan. Bogor. 
9. Juliano, B.O. 1972. The Rice Caryopsis and its Composition. Di dalam Houston, D.F. (eds). Rice Chemistry and Technologi. American Association of Cereal Chemis in Corporated. St. Paul. Minnesota.

10. Lesmono, T. 2005. Kajian Pemanfaatan Limbah Sludge IPAL Industri Pulp dan Kertas sebagai Pupuk Tanaman. [Thesis]. Program Pascasarjana, IPB. Bogor.

11. Osman, Fiyanti. 1996. Memupuk Padi dan Palawija. Penebar Swadaya. Jakarta.

12. Obata, Hitoshi. 1995. Micro Essential Elements. Di dalam: Takane $\mathrm{M}$ et al, editor. Science of The Rice Plant: Physiologi. Volume ke-2. Food and Agriculture Policy Research Center. Japan: Tokyo. Hlm 402-419.

13. Richard, T. 1996. The Compost Process. Department of Agricultural and Biological Engineering Cornell University, New York.

14. Saeni, M.S. 1997. Penentuan Tingkat Pencemaran Logam Berat dengan Analisis Rambut. Orasi Ilmiah Guru Besar Tetap Ilmu Kimia Lingkungan Fakultas Matematika dan Ilmu Pengetahuan Alam Institut Pertanian Bogor.

15. Salt, B.E., R.C.Price, I.J. Pickering., I. Rastein. 1995. Mechanisme of Cadmium Mobility and Accumulation in India Mustard.

16. Sanchez, P.A.1976. Properties and Management of Soil in The Tropics. John and Sons., 1427-1433 .

17. Scott, G.M., S. Abubar \& A. Smith. 1995. Sludge Characteristic and Disposal Alternatives for The Pulp and Paper Industry. Proceedings of The 1995 International Envirotmental Conference. May 7-10. Atlanta.

18. Suharto. 2005. Dampak Pencemaran Logam Timbal (Pb) Terhadap Kesehatan Masyarakat. http://www.pbpersi.co.id,14 Mei 2006. Pkl. 11.47 WIB.

19. Vouk, V. 1986. General Chemistry of Metals in Freiberg L.,Nordberg G.F. \& Vouk, V.B. (eds). Handbook on The Toxicollogy of Metal. Elseiver. New York.

20. Winarno, F.G. 1997. Kimia Pangan dan Gizi. PT Gramedia Pustaka Utama. Jakarta. 